Over the Horizon 



\section{Over the Horizon}

\section{Time, Uncertainty, and the Rise of Great Powers}

\section{David M. Edelstein}

Cornell University Press

Ithaca and London 
Copyright $@ 2017$ by Cornell University

All rights reserved. Except for brief quotations in a review, this book, or parts thereof, must not be reproduced in any form without permission in writing from the publisher. For information, address Cornell University Press, Sage House, 512 East State Street, Ithaca, New York 14850.

First published 2017 by Cornell University Press

Printed in the United States of America

Library of Congress Cataloging-in-Publication Data

Names: Edelstein, David M., author.

Title: Over the horizon : time, uncertainty, and the rise of great powers / David M. Edelstein.

Description: Ithaca : Cornell University Press, 2017. I Includes bibliographical references and index.

Identifiers: LCCN 2017004752 (print) | LCCN 2017005598 (ebook) | ISBN 9781501707568 (cloth : alk. paper) | ISBN 9781501712081 (epub/mobi) I ISBN 9781501709449 (pdf)

Subjects: LCSH: Great powers-History. I World politics. I Time perception-Political aspects. I Uncertainty-Political aspects. Classification: LCC D31 .E34 2017 (print) | LCC D31 (ebook) | DDC 320.9-dc23

LC record available at https://lccn.loc.gov/2017004752

Cornell University Press strives to use environmentally responsible suppliers and materials to the fullest extent possible in the publishing of its books. Such materials include vegetable-based, low-VOC inks and acid-free papers that are recycled, totally chlorine-free, or partly composed of nonwood fibers. For further information, visit our website at www.cornellpress.cornell.edu. 
To Levi and Gabriel 
